\title{
A Tool for Academic Libraries to Prioritize Leadership Competencies
}

\section{Gabrielle K.W. Wong}

As part of a research project, the author conducted a survey about Hong Kong academic librarians' perception on leadership capabilities. The survey made use of the Leadership Competencies Model developed for the Library Leadership and Management Association (LLAMA). The results draw attention to a subset of competencies and expose perceptual differences between librarians at different leadership levels. By visualizing the data in a quadrant view, creating a leadership competency profile, the method can shed light on significant areas in leadership capabilities and trigger discussion among librarians on their understanding and assumptions about these attributes. The survey demonstrated a method that can be experimented by libraries and consortia beyond the Hong Kong sample. Such effort should eventually lead to constructive development strategies.

For academic libraries, effective leadership is crucial to drive service innovation along with changes in technology and higher education environment. Developing leadership capabilities is a complex and longitudinal process, one that librarians do not yet understand well enough. Libraries are keen to expand leadership capacity, and many librarians join leadership programs of various kinds. However, leadership development requires much more than episodic training; systemic and strategic planning is vital for libraries as well as librarians. There is little evidence that libraries are designing strategic leadership development or implementing intentional succession planning. Specifically, libraries do not have a coherent approach to understand what capabilities can facilitate librarians' leadership performance; such understanding should be very helpful for building leadership development strategies.

As part of a qualitative research project to explore leadership development in Hong Kong academic libraries and librarians, the author conducted a survey to solicit librarians' perception on leadership capabilities. The survey made use of the Leadership Competencies Model developed for the Library Leadership and Management Association (LLAMA) of ALA. ${ }^{1}$ The results highlight the competencies that are of particular interest to the sampled group of librarians; they expose perceptual differences between librarians at different levels in an organizational hierarchy. In particular, presenting the survey data in a chart with four quadrants, resulting in a leadership competency profile, can be a powerful way to visualize perceptual differences of various competencies. It further suggests additional competencies that may enrich the model.

\footnotetext{
*Gabrielle K.W. Wong is an EdD candidate at the University of Hong Kong; email: gabiwong@gmail.com; lbgabi@ ust.hk. (2019 Gabrielle K.W. Wong, Attribution-NonCommercial (http://creativecommons.org/licenses/by-nc/4.0/) $C C B Y-N C$.
} 
The survey and its data analysis demonstrate a methodical approach that directs attention to significant areas in leadership, which in turn triggers discussion among librarians on their understanding and assumptions about these attributes. It should potentially lay a foundation on which strategic leadership development can be built. This study reports the design and data analysis of the survey and discusses how the method may be used by other libraries to inform their leadership development initiatives.

\section{Literature Review}

Library literature on leadership slants toward studying directors or titled heads. ${ }^{2}$ Leadership development activities reported include training program evaluation and mentorship experiences; study of development through workplace learning is relatively rare, and evidence of strategic approach is sparse. On discussing what attributes make effective library leaders, there were more articles of anecdotal experience sharing than empirical studies. Very few research studies explore how different leadership capabilities play out at different organizational levels.

Professional librarians exercise leadership whenever they influence others to achieve common goals. Leadership is not limited to those carrying managerial titles; it happens at all levels of an organization. At the senior administrative level, strategic leadership provides vision and directions to support the affiliated institution. At the team or project environment, tactical leadership is essential for implementing operations. ${ }^{3}$ At a junior level, emergent leadership may come from early-career librarians without any assigned titles who can bring forward new ideas and insights that are more salient from the front line. ${ }^{4}$ However, library literature tends to approach leadership with a focus on librarians with official authority, often conflating the roles of managers and leaders.

The contrast of leadership versus management has generated voluminous discussion in literature. Some argue that they are synonymous, in the sense that leadership is one facet of the management role. Others see significant distinctions, portraying leaders as persons who develop visions and inspire people to new directions, whereas managers are persons who monitor progress to achieve order and control. ${ }^{5}$ Kotter highlighted that "management is about coping with complexity," while "leadership, by contrast, is about coping with change." ${ }^{\prime \prime}$ The two functions are both equally necessary for running effective organizations. ${ }^{7}$ Returning to the context of academic libraries, similar to many business organizations, often the two functions fall on the shoulders of the same individuals carrying official positions with assigned responsibility and authority. Therefore, librarians easily use the terms "leaders" and "managers" interchangeably, bringing further confusion when we explore leadership at different levels and design leadership development.

Leaders develop leadership capabilities in a continuous, longitudinal process throughout their careers. The effort attends not only to the development of individuals' knowledge and skills, but also the leadership capacity of organizations as collectives. ${ }^{8}$ Leadership development benefits libraries by building a healthy and agile talent pool for succession planning; it also addresses the need of individual librarians for career and personal growth. Being increasingly aware of the importance of effective leadership to move academic libraries forward when our operation environment changes, librarians have been paying more attention and effort in leadership development. Much of it is reflected from the proliferation of leadership programs over the world, particularly in North America, Europe, Australia, and also in Hong Kong. ${ }^{9}$ Many programs are reviewed and evaluated. ${ }^{10}$ In-house programs tailor-made for in- 
dividual libraries also prove to be an effective alternative. ${ }^{11}$ While the literature reports a lot of positive impact from various training activities, the links between program missions and targeted skills are usually not clear.

Apart from formal programs, workplace learning is a major source of leadership growth. Challenging work experience, networking, researching, professional writing, mentoring, and coaching facilitate the professional growth of librarians. ${ }^{12}$ As Mech put it: "The development of leaders is largely a matter of continued individual self-development abetted by opportunities provided by the organization and the individual."13

With this understanding, libraries should strive to design leadership development in a strategic manner with long-term plans, incorporating structured training and mentorship support as well as workplace challenges. Leaving leadership development to serendipity is detrimental to the profession and the professionals therein.

It appears that not many libraries have a strategic approach to leadership development. Most of the literature reports evaluation and assessment of formal programs and practices such as mentorship. One researcher worked on developmental experiences at workplace: Harris-Keith explored leadership skills of directors and what positions offered development advantages. ${ }^{14}$ A systemic endeavor was the in-house leadership development program in University of Saskatchewan Library; the improvement in leadership qualities and staff engagement was measurable in their annual staff survey. ${ }^{15}$ In Australia, University of Wollongong Library involved an external consultant to design a multifaceted program, ${ }^{16}$ and University of Melbourne had a systematic development plan to uncover employees' potential at a range of levels. ${ }^{17}$ These outstanding cases should inspire more libraries to take on strategic leadership development rather than relying on episodic training programs.

From the perspective of leadership development, desirable leadership capabilities should be the learning outcomes that guide the design of developmental activities and programs. Some organization researchers conceptualize leaders' qualities in terms of knowledge, skills, and abilities. For example, T. Mumford's research team surveyed job skill requirements to build a "strataplex model" with cognitive skills, interpersonal skills, business and strategic knowledge. ${ }^{18}$ Other scholars use a different dimension by looking at behaviors or strategies of successful business leaders. One well-known example is the Five Practices for Exemplary Leadership: Challenge the process, Inspire shared vision, Enable others to act, Model the way, Encourage the heart. ${ }^{19}$

Within librarianship, some articles reported leader qualities based on anecdotal experiences, usually authored by seasoned library leaders; fewer were empirical studies. A prominent series of studies by Hernon and his colleagues used job posting analysis, interviews, and the Delphi method to identify attributes of directors in major research libraries in North America. ${ }^{20}$ Emotional intelligence became a focused area in later studies. ${ }^{21}$ Lewis reviewed what competencies were highly valued at the executive level in academic libraries; he found that there is a universality of leadership competencies across professional fields. ${ }^{22}$ Le's study of library leaders identified five leader qualities. ${ }^{23}$ Martin surveyed how followers described positive leaders; he found seven themes for past leaders and six themes of future leader traits. ${ }^{24}$

With various lists of desirable leadership capabilities identified, there seems to be a dearth of effort in connecting them to leadership development. For example, there has been little research exploring which skills are more difficult to acquire than others, and what library experience facilitates the development of those skills. ${ }^{25}$ There seems to be a gap between "knowing these qualities are important" and "helping librarians to develop these qualities." 
Apart from the search for desirable leadership attributes, the literature also helps to clarify the understanding of leadership capabilities. Many of these capabilities are not mutually independent constructs; instead, they are often clusters of interrelated attributes. Leadership is a complex phenomenon involving interactions between people and their social context; therefore, taxonomies of qualities and behaviors relating to effective leadership should reflect the fluidity of describing human characters. ${ }^{26}$ Leadership capabilities are essentially "a complex mix of behavioral, cognitive, and social skills", ${ }^{27}$ and often they are interwoven. For example, "respect" is an important component in a leadership relationship; it is closely associated with the concept of trust. The two constructs share similar sources and are proposed to be antecedents of each other ${ }^{28}$ Among the qualities frequently identified as desirable, some are more trait-like, such as intelligence and personality; others are more skill- or behavior-based, such as problem solving. Researchers generally conceptualize them as two separate categories: the former is more or less the basis for the latter. For example, in a study of teacher leadership, teachers' initial cognitive and psychological capacities are conceptualized as moderators that affect the receptivity, readiness, and ability to learn. ${ }^{29}$ In M. Mumford's leadership skills model, individual attributes including cognitive ability, motivation, and personality are separated from leader competencies such as problem-solving skills, social judgment skills, and knowledge. ${ }^{30}$ Similarly, Bartram, Robertson, and Callinan view personal attributes as competency potential rather than competency; they affect a person's capability to behave competently in the workplace. ${ }^{31}$

The competency approach identifies desirable skills by targeting attributes directly contributing to performance and outcomes in a work environment. Other than this premise, definitions of competency diverge. Giesecke and McNeil define core competencies as "the skills, knowledge, and personal attributes that contribute to an individual's success in a particular position," 32 while Bartram, Robertson, and Callinan see them as "sets of behaviors that are instrumental in the delivery of desired results or outcomes." ${ }^{33}$ In management literature, competency frameworks are intended for measuring performance, promoting productive behaviors, or articulating organizational values. ${ }^{34}$ In library literature, the purpose of competency standards are not that explicitly established. Major professional library associations established core competency standards in a number of areas including academic libraries, school libraries, reference services, technical services, and the like, mainly to describe what qualities professionals should possess. ${ }^{35}$ In the area of library leadership, a team of librarians developed the Leadership Competencies Model for Library Leadership and Management Association (LLAMA) through consulting literature and interviewing library leaders. ${ }^{36}$ The model comprises 17 competencies grouped under four meta-competencies: Cognitive Ability, Vision, Interpersonal Effectiveness, and Managerial Effectiveness. The competencies are based in behavior; each is defined by a phrase (or phrases) that begin with an active verb. At one point of the construction process, the project team considered including a cluster of personal attributes, but they eventually decided otherwise because the four meta-competencies focused on behaviors, not on individuals' characters. Perhaps it was for the same reason of being behavioral-focused, the model does not explicitly list skills relating to emotional intelligence. It is important to note that the 17 competencies are not mutually exclusive constructs; they are interconnected. Furthermore, one competency may include multiple skills. The model is not meant to be prescriptive; yet the project team believed that library leaders lacking some or many of these competencies would find it difficult to initiate, facilitate, and deliver suc- 
cessful services. ${ }^{37}$ However, there has been little literature on how well the model describes library leaders, whether there are major gaps, or how libraries may apply this in organizational development.

As discussed in previous sections, library literature on leadership is often about library directors and senior executives; fewer studies approach leadership from the perspective of librarians at other levels. ${ }^{38}$ Although it can be anticipated that librarians at different levels exercise different sets of leadership capabilities, we know little about the issue, as exploration into such variations is lacking in the library literature. One study about middle managers highlighted the importance of being able to collaborate, motivating others and anticipating trends. ${ }^{39}$ Young librarians shared their leadership experiences and described how a proactive and creative mindset facilitated breakthroughs in reaching out for potential collaborators, bridging service needs and gaps, convincing supervisors and peers. ${ }^{40}$ There appears to be no study contrasting capabilities required at different organizational levels in libraries.

This article reports the findings of a survey of academic librarians in Hong Kong. The survey used the Leadership Competency Model to solicit librarians' perception of leadership capabilities in the attempt to reveal the areas significant to their work performance. Apart from identifying significant competencies, the survey data uncovers a difference in skill perception at different leadership roles and reveals a more complex picture of librarians' leadership context and development aspiration. More important, the survey method and data analysis demonstrate a workable way for other libraries or consortia to explore leadership capabilities using a set of common vocabulary, with which they can initiate discussion on how leadership competencies play out among their librarians at different levels, and to provide basis for further discourse on leadership competencies and leadership experiences relevant to their own context.

\section{Methodology}

The survey was part of the data collection for the author's doctoral research on leadership development in academic libraries. The qualitative research aimed to explore how academic libraries and librarians in Hong Kong develop their leadership capacity. The survey was designed to capture a broad picture of librarians' perception on leadership capabilities and their experiences of leadership development, based on which the author conducted subsequent interviews to delve into the complexity of the issue.

Competency frameworks give people a common language for discussing development and career potential issues. ${ }^{41}$ They could "offer a vocabulary with which organizations can articulate and express their priorities and help make sense of the lived experience of people in leadership roles." ${ }^{\prime 2}$ The Competency Model developed for LLAMA ${ }^{43}$ is an appropriate tool serving this purpose in the study. Although the comprehensiveness of the model is still open for discussion, it remains the most structured competency framework in librarianship so far. The model is not meant to prescribe, confine, or define library leaders' behaviors. For this study, it is helpful by providing a common vocabulary for librarians to describe their leadership experiences.

The survey used an anonymous online questionnaire mounted on the software platform Qualtrics. For each of the 17 competencies in the model, respondents rated on two perceptions using two 5-point Likert-type scales: the importance of each competency to a respondent's perception of his or her work performance, and the respondent's interest in developing a spe- 
cific skill or competency further. The ratings were converted to numbers ranging from " 5 " for Very Important or Very Interested, to " 1 " for Very Unimportant or Very Disinterested. Higher numeric values indicate stronger perception on the importance or interest. It would have been informative to include a third rating that solicited respondents to rate their skill levels of each competency; however, to avoid making the questionnaire too complex to respond, the design was limited to two ratings.

To gauge the respondents' collective perception on each competency, two scores, namely the Importance Score and the Interest Score, were compiled by taking the mean of the ratings of importance and interest of each competency respectively. The Importance Score indicates the perceived importance of the competency in relation to their current positions; the Interest Score indicates the level of interest to develop the competency. The two perceptions are distinct but related. A librarian may find one competency important for work performance but may not be interested to learn more about it because of various possible reasons. On the other hand, a competency that is not so important for current job duties may arouse interest for learning.

The questions are listed in appendix A.

\section{Academic Libraries in Hong Kong}

Higher education in Hong Kong is dominated by the eight publicly funded universities. ${ }^{44}$ They vary in size and focus: from a liberal arts university of about 3,000 students to comprehensive universities accommodating more than 20,000 students. Many Hong Kong universities are competitive in international university rankings. English is used in most teaching and business communication; a considerable proportion of students and faculty is not from Hong Kong. The corresponding eight academic libraries, despite being independent organizations, communicate and collaborate closely under the umbrella of the Joint University Librarians Advisory Committee (JULAC) ${ }^{45}$ Librarians normally hold postgraduate degrees in LIS or related fields. Using the library staff lists of the eight JULAC libraries in August 2017, there were approximately 170 professional librarians at this group of eight institutional libraries. The majority was ethnic Chinese, likely with English as their second language.

For this research, five out of eight of the JULAC directors agreed to participate. Their consent allowed the distribution of the survey link to their librarians and to gather additional information in the subsequent part of the study. Anonymity was guaranteed when publishing the findings; no institutional or personal identity would be disclosed.

\section{Survey Results}

The online questionnaire was opened in October 2017 for five weeks. An invitation email with the link to the questionnaire was distributed to about 120 librarians in the five participating libraries. It received 37 usable responses, which amounted to a 31 percent response rate. The responses were analyzed in an Excel spreadsheet.

Librarians from all five participating libraries replied, although the response rates from each institution varied. Eleven respondents did not identify their affiliations (see table 1).

Most respondents carried leadership responsibilities at their current positions; 14 of them were unit heads, and 13 of them were project leaders without an official headship (see table 2).

About one-third had worked in the field for more than 20 years (see table 3 ). 


\begin{tabular}{|l|c|}
\hline \multicolumn{2}{|c|}{ Respondents' Affiliations } \\
\hline Library & $\begin{array}{c}\text { Number of } \\
\text { Respondents }\end{array}$ \\
\hline Library A & 4 \\
\hline Library B & 9 \\
\hline Library C & 2 \\
\hline Library D & 5 \\
\hline Library E & 6 \\
\hline Not identified & 11 \\
\hline Total & $\mathbf{3 7}$ \\
\hline $\begin{array}{l}\text { Note: As the researcher guaranteed anonymity to the } \\
\text { participating libraries, the staff size in each library } \\
\text { are not disclosed here because the figures will easily } \\
\text { reveal the identity of the institutions. }\end{array}$ \\
\hline
\end{tabular}

\begin{tabular}{|l|c|}
\hline \multicolumn{2}{|c|}{ TABLE 2} \\
\hline & $\begin{array}{c}\text { Number of } \\
\text { Respondents }\end{array}$ \\
\hline $\begin{array}{l}\text { Unit heads, with project and } \\
\text { supervising responsibility }\end{array}$ & 11 \\
\hline $\begin{array}{l}\text { Unit heads, with supervising } \\
\text { responsibility }\end{array}$ & 3 \\
\hline $\begin{array}{l}\text { Project leaders with supervising } \\
\text { responsibility }\end{array}$ & 8 \\
\hline Project leaders with no supervisee & 5 \\
\hline No leadership role & 3 \\
\hline Not identified & 7 \\
\hline Total & $\mathbf{3 7}$ \\
\hline
\end{tabular}

\begin{tabular}{|l|c|}
\hline \multicolumn{2}{|c|}{$\begin{array}{c}\text { TABLE 3 } \\
\text { Years Of Library Working } \\
\text { Experience }\end{array}$} \\
\hline & $\begin{array}{c}\text { Number of } \\
\text { Respondents }\end{array}$ \\
\hline Fewer than 2 years & 1 \\
\hline 3-10 years & 9 \\
\hline 11-20 years & 8 \\
\hline More than 20 years & 12 \\
\hline Not identified & 7 \\
\hline Total & $\mathbf{3 7}$ \\
\hline
\end{tabular}

\begin{tabular}{|l|c|c|c|c|c|c|}
\hline \multicolumn{7}{|c|}{ TABLE 4 } \\
\hline & $\begin{array}{c}<\mathbf{2} \\
\text { Years }\end{array}$ & $\begin{array}{c}\mathbf{3 - 1 0} \\
\text { Years }\end{array}$ & $\begin{array}{c}\mathbf{1 1 - 2 0} \\
\text { Years }\end{array}$ & $\begin{array}{c}\mathbf{>} \mathbf{2 0} \\
\text { Years }\end{array}$ & $\begin{array}{c}\text { Not } \\
\text { Identified }\end{array}$ & Total \\
\hline Unit heads & 1 & 2 & 2 & 9 & & 14 \\
\hline $\begin{array}{l}\text { Project leader } \\
\text { + Supervisor }\end{array}$ & & 3 & 3 & 2 & & 8 \\
\hline Project leader & & 2 & 3 & & & 5 \\
\hline Supervisor & & & & & & 0 \\
\hline None of these & & 2 & & 1 & & 3 \\
\hline Not identified & & & & & 7 & 7 \\
\hline Total & $\mathbf{1}$ & $\mathbf{9}$ & $\mathbf{8}$ & $\mathbf{1 2}$ & $\mathbf{7}$ & $\mathbf{3 7}$ \\
\hline
\end{tabular}

Majority of those with 20 or more years of working experience were unit heads (see table 4).

Regarding their areas of specialization, respondents could choose multiple areas from the list given in the questionnaire. About half of them chose a single area (see table 5).

\begin{tabular}{|l|c|}
\hline \multicolumn{2}{|c|}{ PABLE 5 } \\
\hline & $\begin{array}{c}\text { Number of } \\
\text { Respondents }\end{array}$ \\
\hline One area & \\
\hline Administration & 3 \\
\hline Access services (e.g. lending, interlibrary loan) & 1 \\
\hline Information services (e.g. reference, information literacy) & 7 \\
\hline Research services (e.g. data service, scholarly communication, digital scholarship) & 2 \\
\hline Collection services (e.g. acquisitions, cataloguing, collection development) & 1 \\
\hline Systems and facilities (e.g. ILS, computing equipment, space management) & 3 \\
\hline Others & 1 (public relations) \\
\hline \multicolumn{1}{|c|}{ Subtotal } & $\mathbf{1 8}$ \\
\hline
\end{tabular}




\begin{tabular}{|l|c|}
\hline Two areas & \multicolumn{1}{|c|}{} \\
\hline Administration + Information services & 1 \\
\hline Administration + Collection services & 1 \\
\hline Administration + Systems and facilities & 1 \\
\hline Access services + Systems and facilities & 2 \\
\hline Information services + Research services & 1 \\
\hline Research services + Special collections / archives & $\mathbf{7}$ \\
\hline & \multicolumn{1}{|c|}{ Subtotal } \\
\hline Three areas & 1 \\
\hline Access services + Information services + Collection services & 1 \\
\hline Access services + Systems and facilities + Others [special projects] & $\mathbf{3}$ \\
\hline Information services + Research services + Collection services & 1 \\
\hline & \\
\hline Four areas & 1 \\
\hline Administration + Access services + Information services + Collection services & 2 \\
\hline Information services + Research services + Collection services + Others [outreach] & 7 \\
\hline Subtotal & $\mathbf{3 7}$ \\
\hline Not identified & Total \\
\hline
\end{tabular}

"Information services" was a major area chosen by the respondents (see table 6); those who chose "others" described their responsibilities as special projects, user outreach, public relations, and marketing.

\begin{tabular}{|l|c|}
\hline \multicolumn{2}{|c|}{ TABLE 6 } \\
\hline & $\begin{array}{c}\text { Number of } \\
\text { Respondents }\end{array}$ \\
\hline Administration & 7 \\
\hline Access services (such as lending, interlibrary loan) & 5 \\
\hline Information services (such as reference, information literacy) & 14 \\
\hline Research services (such as data service, scholarly communication, digital scholarship) & 7 \\
\hline Collection services (such as acquisitions, cataloguing, collection development) & 6 \\
\hline Systems and facilities (such as ILS, computing equipment, space management) & 6 \\
\hline Special collections, archives & 1 \\
\hline Others & 3 \\
\hline Total & $\mathbf{4 9}$ \\
\hline
\end{tabular}

The survey resulted in 17 Importance Scores, ranging from 3.97 to 4.89; all but one was above the "Important" mark (4). The Interest Scores range from 3.78 to 4.44. The scores in bold in table 7 are the three highest scores in the corresponding scales (see table 7). 


\begin{tabular}{|c|c|c|c|c|c|}
\hline \multicolumn{6}{|c|}{$\begin{array}{c}\text { TABLE } 7 \\
\text { Importance Scores And Interest Scores Of The } 17 \text { Competencies }\end{array}$} \\
\hline \multicolumn{3}{|c|}{ Cognitive Ability } & \multicolumn{3}{|c|}{ Vision } \\
\hline & Importance & Interest & & Importance & Interest \\
\hline Problem Solving & 4.78 & 4.22 & Global Thinking & 4.25 & 4.25 \\
\hline Decision Making & 4.69 & 4.08 & Creative/Innovative & 4.28 & 4.44 \\
\hline Reflective Thinking & 4.42 & 4.14 & Forward Thinking & 4.47 & 4.36 \\
\hline \multicolumn{3}{|c|}{ Interpersonal Effectiveness } & \multicolumn{3}{|c|}{ Managerial Effectiveness } \\
\hline & Importance & Interest & & Importance & Interest \\
\hline Culturally Competent & 4.03 & 3.78 & Manage Change & 4.58 & 4.42 \\
\hline Accountability & 4.58 & 3.86 & Resource Management & 4.25 & 3.94 \\
\hline Team Building & 4.42 & 4.31 & Strategic Planning & 4.47 & 4.31 \\
\hline Development & 3.97 & 4.00 & Collaboration & 4.56 & 4.44 \\
\hline Inspirational/Motivational & 4.47 & 4.19 & Flexibility/Adaptability & 4.53 & 4.19 \\
\hline Communication Skills & 4.89 & 4.22 & & & \\
\hline
\end{tabular}

\section{Rankings of Scores}

The competencies are ranked in descending order of the two scores (see table 8). The top 3 important competencies are Communication Skills, Problem Solving, and Decision Making.

\begin{tabular}{|l|l|l|l|l|l|}
\hline \multicolumn{7}{|c|}{ Competencies Rankings } \\
\hline Importance Scores Ranking & 4.89 & 1 & Creative/Innovative & 4.44 \\
\hline 1 & Communication Skills & 4.78 & 1 & Collaboration & 4.44 \\
\hline 2 & Problem Solving & 4.69 & 3 & Manage Change & 4.42 \\
\hline 3 & Decision Making & 4.58 & 4 & Forward Thinking & 4.36 \\
\hline 4 & Accountability & 4.58 & 5 & Team Building & 4.31 \\
\hline 4 & Manage Change & 4.56 & 5 & Strategic Planning & 4.31 \\
\hline 6 & Collaboration & 4.53 & 7 & Global Thinking & 4.25 \\
\hline 7 & Flexibility / Adaptability & 4.47 & 8 & Problem-Solving & 4.22 \\
\hline 8 & Forward Thinking & 4.47 & 8 & Communication Skills & 4.22 \\
\hline 8 & Inspirational / Motivational & 4.47 & 10 & Inspirational / Motivational & 4.19 \\
\hline 8 & Strategic Planning & 4.42 & 10 & Flexibility / Adaptability & 4.19 \\
\hline 11 & Reflective Thinking & 4.42 & 12 & Reflective Thinking & 4.14 \\
\hline 11 & Team Building & 4.28 & 13 & Decision Making & 4.08 \\
\hline 13 & Creative/Innovative & 4.25 & 14 & Development & 4.00 \\
\hline 14 & Global Thinking & 4.25 & 15 & Resource Management & 3.94 \\
\hline 14 & Resource Management & 4.03 & 16 & Accountability & 3.86 \\
\hline 16 & Culturally Competent & 3.97 & 17 & Culturally Competent & 3.78 \\
\hline 17 & Development & & & & \\
\hline
\end{tabular}


The top 3 that respondents were interested to develop are Creative/Innovative, Collaboration, Manage Change. On a number of occasions, two or more competencies share the same ranking positions because they have the same scores.

It is worth noting that the two rankings are considerably different. The top three "Important" competencies are under the meta-competencies of Cognitive Abilities and the group of Interpersonal Effectiveness; while the top three "Interested" competencies are under the other two groups: Vision, and Managerial Effectiveness. Among the top six items in both scales, there are only two in common: Collaboration and Manage Change. Apparently, for this group of respondents, competencies that they perceive as most important for their work performance are not necessarily those to which they aspire the most. In particular, two competencies show large contrast in the two ranking positions: Accountability is fourth in the Importance ranking but second to last in the Interest ranking; on the contrary, Creative/Innovative is relatively low in the Importance ranking, but it is the top in the Interest ranking. Another competency with relatively big difference on the two rankings is Decision Making, which is ranked as third in Importance, but at the lower end in Interest (see table 9).

\begin{tabular}{|c|c|c|c|c|c|}
\hline \multicolumn{6}{|c|}{$\begin{array}{c}\text { TABLE } 9 \\
\text { Comparing Ranking Positions In The Two Scales }\end{array}$} \\
\hline & \multicolumn{2}{|c|}{ Importance } & \multicolumn{2}{|c|}{ Interest } & \multirow{2}{*}{$\begin{array}{c}\begin{array}{c}\text { Difference in } \\
\text { Rank Positions }\end{array} \\
\text { (a) - (b) }\end{array}$} \\
\hline & $\begin{array}{c}\text { Rank } \\
\text { Position (a) }\end{array}$ & Score & $\begin{array}{c}\text { Rank } \\
\text { Position (b) }\end{array}$ & Score & \\
\hline \multicolumn{6}{|l|}{ Cognitive Ability } \\
\hline Problem Solving & 2 & 4.78 & 8 & 4.22 & -6 \\
\hline Decision Making & 3 & 4.69 & 13 & 4.08 & -10 \\
\hline Reflective Thinking & 11 & 4.42 & 12 & 4.14 & -1 \\
\hline \multicolumn{6}{|l|}{ Interpersonal Effectiveness } \\
\hline Culturally Competent & 16 & 4.03 & 17 & 3.78 & -1 \\
\hline Accountability & 4 & 4.58 & 16 & 3.86 & -12 \\
\hline Team Building & 11 & 4.42 & 5 & 4.31 & +6 \\
\hline Development & 17 & 3.97 & 14 & 4.00 & +3 \\
\hline Inspirational/Motivational & 8 & 4.47 & 10 & 4.19 & -2 \\
\hline Communication Skills & 1 & 4.89 & 8 & 4.22 & -7 \\
\hline \multicolumn{6}{|l|}{ Vision } \\
\hline Global Thinking & 14 & 4.25 & 7 & 4.25 & +7 \\
\hline Creative/Innovative & 13 & 4.28 & 1 & 4.44 & +12 \\
\hline Forward Thinking & 8 & 4.47 & 4 & 4.36 & -4 \\
\hline \multicolumn{6}{|l|}{ Managerial Effectiveness } \\
\hline Manage Change & 4 & 4.58 & 3 & 4.42 & +1 \\
\hline Resource Management & 14 & 4.25 & 15 & 3.94 & -1 \\
\hline Strategic Planning & 8 & 4.47 & 5 & 4.31 & +3 \\
\hline Collaboration & 6 & 4.56 & 1 & 4.44 & +5 \\
\hline Flexibility/Adaptability & 7 & 4.53 & 10 & 4.19 & +3 \\
\hline
\end{tabular}


The two scales interact to shed light on which competencies are more significant for effective leadership and leadership development. This can be visualized using a chart contrasting the two scores of each competency (see figure 1).

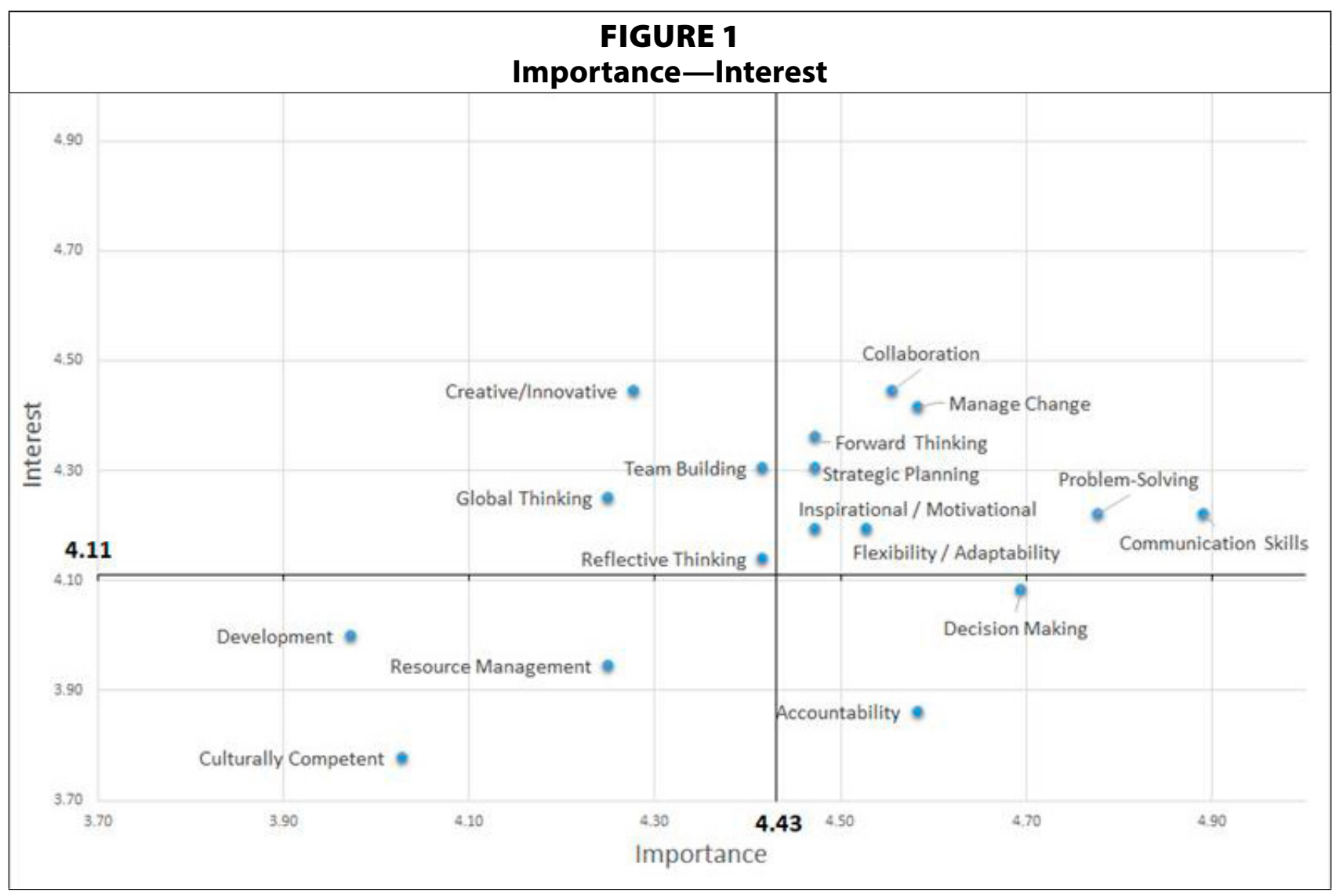

The chart uses the two scales as coordinates; the 17 competencies fall into four sectors. The division lines are determined by the midpoints of the scores on the corresponding scales. The figure shows four competencies at an outer rim on the "high ends quadrant": Collaboration, Manage Change, Problem Solving, and Communication Skills. It also shows another group of four competencies in this priority quadrant: Forward Thinking, Strategic Thinking, Inspirational/Motivational, Flexibility/Adaptability. This visualization depicts a leadership competency profile of the group of respondents; its application will be explored further in the discussion section.

\section{Ratings by Respondents Carrying Different Leadership Roles}

Unit heads $(n=14)$ and project leaders $(n=13)$ rated the competencies differently in both scales (see figures 2 and 3).

For each respondent, the sum of all the 17 importance ratings can be taken as an indicator of how much the individual values these skills collectively; similarly, the sum of one's interest ratings on the 17 competencies may indicate an overall interest level of this respondent in developing leadership skills. Tabulating these rating summations reveals differences between the Unit Head Group and the Project Leader Group (see table 10); the corresponding figures for the whole sample are included for comparison. 

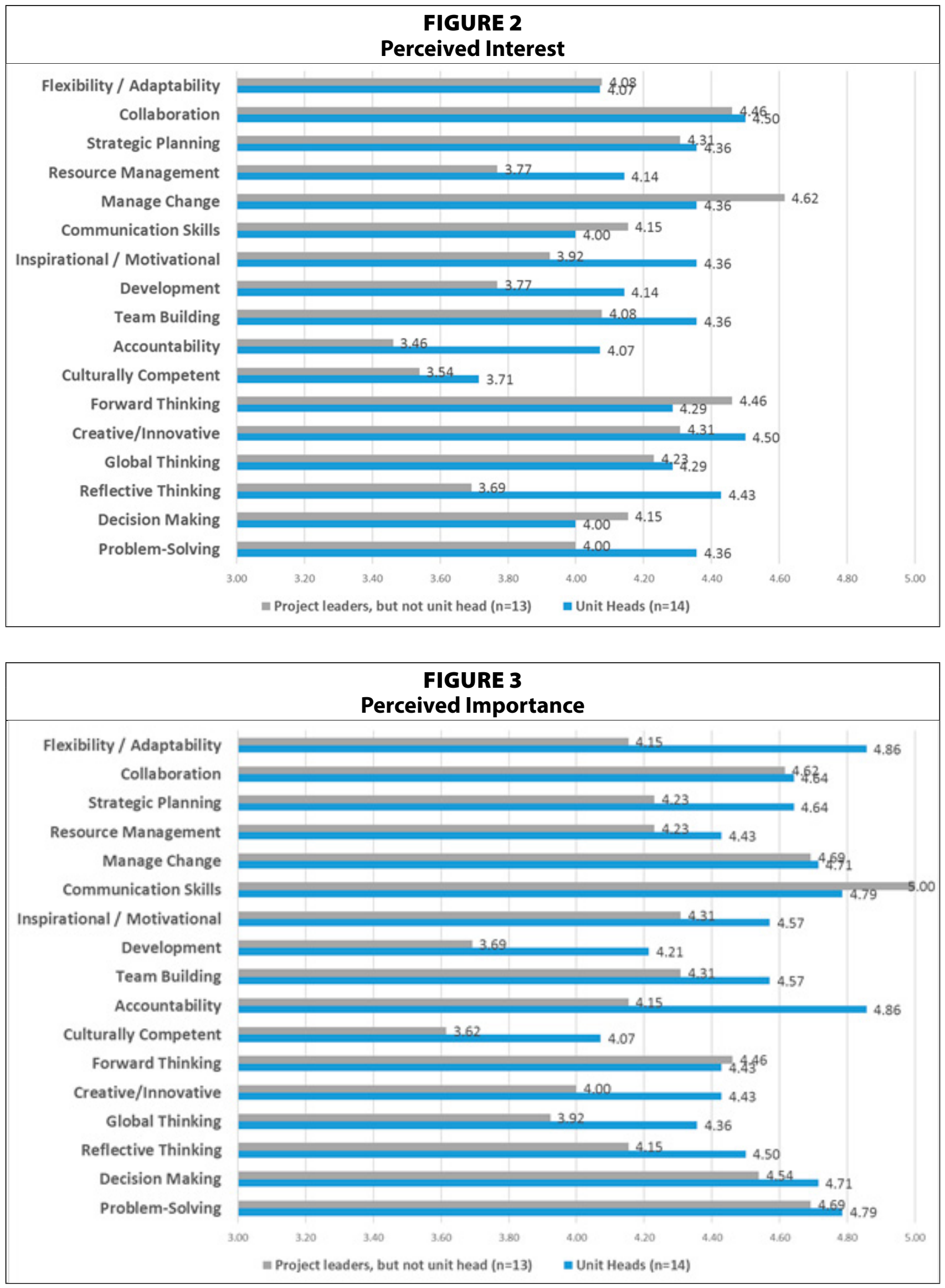


\begin{tabular}{|l|c|c|c|}
\hline \multicolumn{4}{|c|}{ TABLE 10 } \\
\hline & Overall Ratings of Unit Heads vs Project Leaders \\
\hline & Unit Heads & Project Leaders & All Respondents \\
\hline Average Total Importance Ratings & 77.57 & 72.77 & 75.64 \\
\hline Average Total Interest Ratings & 71.93 & 69.00 & 71.17 \\
\hline
\end{tabular}

For both Importance perception and overall Interest, the Unit Head Group rated higher than the Project Leader Group. This suggests that librarians in titled positions are more concerned with leadership competencies.

Both groups found Communication Skills and Problem Solving highly important; but, for their interest to develop, only Collaboration appeared in the top choices of both groups (see table 11).

\begin{tabular}{|l|l|l|}
\hline \multicolumn{3}{|c|}{ Highly Rated Competencies of the Two Groups } \\
\hline & \multicolumn{1}{|c|}{ Unit Heads } & \multicolumn{1}{c|}{ Project Leaders } \\
\hline $\begin{array}{l}\text { Top Important Competencies } \\
\text { (Score) }\end{array}$ & $\begin{array}{l}\text { Accountability; Flexibility/ } \\
\text { Adaptability (4.86) } \\
\text { Communication Skills; } \\
\text { Problem Solving (4.79) }\end{array}$ & $\begin{array}{l}\text { Communication Skills (5.00) } \\
\text { Manage Change; Problem Solving (4.69) }\end{array}$ \\
\hline $\begin{array}{l}\text { Top Interested Competencies } \\
\text { (Score) }\end{array}$ & $\begin{array}{l}\text { Collaboration; Creative/ } \\
\text { Innovative (4.50) } \\
\text { Reflective Thinking (4.43) }\end{array}$ & $\begin{array}{l}\text { Manage Change (4.62) } \\
\text { Forward Thinking; Collaboration (4.46) }\end{array}$ \\
\hline
\end{tabular}

The Unit Head Group rated Accountability and Flexibility/Adaptability notably higher, while their interest to develop Reflective Thinking and Accountability was higher than the Project Leader Group (see table 12).

\begin{tabular}{|l|c|c|c|}
\hline \multicolumn{5}{|c|}{ TABLE 12 } \\
\hline & Unit Heads & Project Leaders & Differences in Points \\
\hline Importance Scores & & & \\
\hline Accountability & 4.86 & 4.15 & 0.71 \\
\hline Flexibility/Adaptability & 4.86 & 4.15 & 0.71 \\
\hline Development & 4.21 & 3.69 & 0.52 \\
\hline Culturally Competent & 4.07 & 3.62 & 0.45 \\
\hline Global Thinking & 4.36 & 3.92 & 0.44 \\
\hline Creative/Innovative & 4.43 & 4.00 & 0.43 \\
\hline Interest Scores & & & 0.74 \\
\hline Reflective Thinking & 4.43 & 3.69 & 0.61 \\
\hline Accountability & 4.07 & 3.46 & 0.44 \\
\hline Inspirational/Motivational & 4.36 & 3.92 & 0.37 \\
\hline Resource Management & 4.14 & 3.77 & \\
\hline
\end{tabular}


The results seem to indicate that, overall, unit heads tend to value leadership competencies more than those project leaders who do not carry an official headship. They specifically see the importance of Accountability and Flexibility/Adaptability, on which project leaders pay much less attention. The only competency that project leaders rated higher was Communication Skills, although the difference is small.

\section{Additional Leadership Skills Described in Open Comments}

Fifteen respondents suggested additional skills that they found important for their work performance (see table 13).

\begin{tabular}{|c|c|c|}
\hline \multicolumn{3}{|c|}{$\begin{array}{c}\text { TABLE } 13 \\
\text { Additional Important Skills }\end{array}$} \\
\hline Respondents' Answers & $\begin{array}{c}\text { Related Competencies or } \\
\text { Categories in the Model }\end{array}$ & Remarks \\
\hline Negotiation & Communication Skills; Collaboration & \\
\hline Lead by example & Accountability & \\
\hline $\begin{array}{l}\text { Awareness to local legislation, risk } \\
\text { management, relationship building }\end{array}$ & $\begin{array}{l}\text { Global Thinking; Manage Change; } \\
\text { Team Building }\end{array}$ & \\
\hline Motivation, Delegation & $\begin{array}{l}\text { Inspirational/Motivational; Resource } \\
\text { Management }\end{array}$ & \\
\hline $\begin{array}{l}\text { Negotiation-When conflicts arise, be } \\
\text { able to arrive at a compromise that } \\
\text { satisfies both parties }\end{array}$ & Communication Skills; Collaboration & \\
\hline Lead by example wherever possible. & Accountability & \\
\hline Forbearance & $\begin{array}{l}\text { Problem-Solving; Flexibility/ } \\
\text { Adaptability }\end{array}$ & Emotional intelligence \\
\hline Pay fairness to employees & $\begin{array}{l}\text { Accountability; Inspirational/ } \\
\text { Motivational }\end{array}$ & \\
\hline Kindness, patience, and humility & Interpersonal Effectiveness & Emotional intelligence \\
\hline $\begin{array}{l}\text { My work does not require me to exhibit } \\
\text { any leadership skills. }\end{array}$ & - & \\
\hline Firm, meticulous, tactful, good memory & Managerial Effectiveness & Personal management \\
\hline Project Management & $\begin{array}{l}\text { Manage Change; Resource } \\
\text { Management }\end{array}$ & \\
\hline Openness & Flexibility/Adaptability & \\
\hline Approachable and fair & $\begin{array}{l}\text { Accountability; Inspirational/ } \\
\text { Motivational }\end{array}$ & \\
\hline Coaching and mentoring & Development & \\
\hline
\end{tabular}

Among them, negotiation, leading by example, and being fair were mentioned twice; there were also remarks on traits or attitudes such as forbearance and kindness. Only six respondents suggested additional skills they were interested in developing; those skills included conflict management, international collaboration, relationship building, meeting and time management, succession planning, and skills that can be used to develop employees' talents and engagement. 
Most of these additional skills can be linked to competencies in the LLAMA model. For example, "leading by example" is subsumed under Accountability according to the model description; 46 project management involves knowledge and skills of Manage Change and Resource Management. Other additional skills that do not easily fit in the model tend to be more trait-like, or relate to self-management skills, such as kindness, meticulousness, and time management. Many of these added skills call for emotional intelligence, which is not explicitly mentioned in the model. These comments suggest that the model may be lacking certain vocabulary that leaders use to describe their leadership responsibilities and experiences. The discussion section below will elaborate how adding one meta-competency may complement the existing four in the model.

\section{Discussion}

The findings of the questionnaire survey capture the perception of academic librarians in leadership competencies. The 17 items in the Leadership Competency Model, by definition, are all significant attributes and behaviors for leading successfully in libraries. Yet it is to be expected that certain competencies are more valuable than others to specific groups of librarians, depending on their situational factors such as organizational context, individuals' leadership roles, and personal abilities. Using this questionnaire based on the model to highlight differentials among the competencies can be one possible entry point for libraries to navigate the complexity of leadership capabilities, and hence initiate leadership development planning. This discussion section explores the survey findings and their implications in four areas: what affects librarians' interest to develop leadership capacity, different perception on leadership skills held by unit heads and other librarians, the leadership competency profile chart to initiate discussion for leadership development, and considering the fifth meta-competency in the Competency model.

What drives librarians' interest in developing leadership skills? On the Importance Scale and the Interest Scale, respondents were rating two different perceptions on the competencies. Competencies that librarians find necessary for their work may not be the same as those they want or need to improve. One open comment explains the respondent's thinking when she gave her Interest ratings, showing how previous training affects librarians' interest to develop skills:

"[t]he reason I put neutral on some [of] these is because I have already received training on them and don't feel a really strong need to get more training on them. But if I were a person who had never been trained, or only minimally trained on them, then I would be more interested."

Similarly, confidence in or proficiency of one's skill level may reduce the individual's interest to invest time and resources for further improvement. Librarians who are at a later stage of their careers may have less interest to invest in personal development. On the other hand, a competency that may not be so important to a librarian's work at the current moment may arouse interest as it is perceived to be an important future skill. Other factors that may inhibit interest in continuous learning include the lack of time in one's busy work life and hurdles in applying acquired skills to one's current roles. ${ }^{47}$ 
The findings revealed how unit heads perceive leadership competencies differently from project leaders without official head titles. This is a clear reminder for libraries to look into such differences when planning their leadership development activities. While librarians at all ranks should develop their leadership capabilities, the shift in priorities due to differences in leadership roles or seniority should not be ignored.

Differentials among competencies can trigger meaningful discussion. The leadership competency profile created by plotting the two sets of scores can direct librarians' attention to which fall into the four quarters. Those in the high-importance/high-interest quadrant naturally would become primary targets in leadership development. The rest deserve discussion and reflection as well. For example, if a particular competency falls in the high-importance/ low-interest sector, is it because most librarians have already attained high proficiency in that area, or are there other reasons that hinder librarians' motivation to learn this important skill? Using the common vocabulary from the Competency model, librarians can start discussions on what these competencies mean to their leadership context, their awareness to their own strengths and weaknesses, and how to move forward with leadership development. Using the Hong Kong sample as an example, libraries may organize discussion among librarians along these themes:

- With reference to the competencies identified as significant, namely Collaboration, Manage Change, Problem Solving, and Communication Skills, what do they mean in the workplace? What knowledge and skills are involved in them? How can librarians go about developing such knowledge and skills? Would libraries make longer-term plans to develop staff accordingly?

- Unit heads value Accountability and Adaptability/Flexibility considerably more than project leaders do; why is that so? Would project leaders raise their awareness to these important skills for their career growth and the library's succession plan?

- Culturally Competent was not perceived as significant; why is that so? Although most professionals in the workforce are ethnic Chinese, university communities have a diverse cultural background; does this competency deserve more understanding and more attention?

Last but not least, the survey findings expose some competency descriptors that librarians find important but are absent in the current version of Competency model. What appear to be lacking are certain self-management skills, such as time management and emotional awareness. The study findings suggest that a fifth meta-competency may be included in the model to cover this area. Inspired by the comments in the survey, a Self-Management metacompetency may include three competencies: Time Management/Organization Skills, SelfAwareness, and Self-Regulation. To fully develop the domain and description of this idea is beyond the scope of this paper, but it warrants further exploration and research, as it should be able to fill a perceived gap in the current model.

\section{Limitations}

A number of limitations in the design and implementation of this survey should be noted. The questionnaire did not assess respondents' perception of their leadership skill levels. Such self-rating may not be accurate, yet it may help bridge the gap between the perceived importance and interest to develop. Another weakness in the instrument design is that respondents might have different understandings of what the competencies encompass, although brief 
descriptions of each competency were added in the questionnaire. Part of that could be a language issue, as most respondents used English as their second language, and their English proficiency varied. In addition, many of the competencies may be interpreted differently; for example, some respondents might see communication skill as mainly being articulate, while others might also consider the ability to listen without judgment. Such individual variations might have affected the perception ratings.

\section{Conclusion}

Effective leadership involves the interplay of complex sets of capabilities. A better understanding of leadership capabilities is instrumental for all stakeholders in the profession. Library graduate programs can use the knowledge to prepare new librarians to develop relevant leadership skills and provide frameworks for understanding leadership issues; libraries can have better-informed recruitment, leadership development, and succession planning; and individual librarians can raise their awareness to one's own competency level and work toward career growth. The Leadership Competency Model is a helpful framework to provide structure for exploration and discussion; although some may find the model insufficient for describing leadership comprehensively, it assists but does not limit how libraries and librarians explore their leadership contexts and capabilities.

By soliciting respondents' ratings on the Importance Scale and the Interest Scale, the survey captured librarians' perceptions on leadership capabilities in numeric terms. Descriptive analysis of the results exposed the subsets of competencies that deserve more attention. The results reveal how librarians carrying different leadership roles view these competencies differently. The findings can inform academic libraries in their future endeavors for planning leadership development strategies.

The survey demonstrated how using the Leadership Competency Model and ratings on the two scales can generate scores and rankings that help libraries and librarians to visualize and understand their own leadership competency profiles. Librarians from different regions and different contexts using the same tool will result in very different ranking tables and their own distinctive profiles. They will become useful starting points for designing strategic plans for leadership development effort most relevant to their own context. 


\section{Appendix A: Questionnaire Section 1: Leadership Skills}

Below are 17 leadership skills in 4 categories based on the Core Leadership Competency Model for Librarians (Ammons-Stephens et al., 2009).

Question 1. How important are these competencies for your work performance? Please read the brief explanation of each skill, and give your rating.

[For each skill, respondent rated at this 5-point scale:

Very Important (5) Important (4)Neutral (3) Unimportant (2) Very Unimportant (1)]

\section{Cognitive Ability}

Problem-Solving Solve problem actively, creatively, and holistically

Decision Making Assume responsibility; make sound, timely and transparent decisions

Reflective Thinking Accurately assess shortcomings and assets of the organization; recognize and implement opportunities for continuous improvement

\section{Vision}

Global Thinking Think beyond the library; consider ideas and issues that impact communities on a broader scale

Creative/Innovative Think innovatively; encourage new thoughts and experimentation Forward Thinking Anticipate problems and opportunities; envision consequences; and inspire others to think about possibilities

\section{Interpersonal Effectiveness}

Culturally Competent Exhibit an awareness of and appreciation for diverse cultures and beliefs; foster an environment where all cultures are respected and valued

Accountability Instill trust; assume responsibility for decisions made

Team Building Build effective relationships; actively promote strategic team building Development Actively seek ways to develop staff

Inspirational / Motivational Inspire individuals to succeed; motivate individuals to actively contribute to the library

Communication Skills Actively listen; effectively articulate ideas through verbal and written communication; withhold judgment; give and receive constructive feedback

\section{Managerial Effectiveness}

Manage Change Build internal and external support for change; work to keep transitions running smoothly; demonstrate willingness to take calculated risks

Resource Management Understand cost efficiency and effectiveness; apportion resources equitably; assign projects to colleagues appropriately; act with diligence and care Strategic Planning Identify clear, well-defined outcomes; exhibit planning capabilities for short-term and long-term results

Collaboration Build relationships with community groups and constituents; work with others where sharing resources would be appropriate

Flexibility / Adaptability Exhibit an open mind; maintain steadiness through difficult situations Question 2. Please name any other leadership skills you find important for your work performance. 
Question 3. For the same list of skills, how interested are you to improve on them?

[The same 17 items as above are listed. For each skill, respondent rated at this 5-point scale: Very Interested (5) Interested (4) Neutral (3) Disinterested (2) Very Disinterested (1)] Question 4. Please name any other leadership skills you are interested to develop.

\section{Section 2: Your previous experiences in leadership development}

Much of our professional learning make us better leaders at work. For this study, leadership developmental activities include many forms:

Events or programs on professional expertise or leadership skills, e.g.,

- Training courses, workshops, seminars, etc.

- Conferences, library visits

- Mentorship programs

- Formal feedback exercises

- Action learning

Workplace learning, e.g.,

- Challenging job assignments

- Informal mentoring relations

- Peer sharing

Question 5. Please recall any developmental activities for yourself that were memorable in either a good or bad way. They could be particularly rewarding or disappointing. Describe the activities and explain what made them good or bad.

\section{Section 3: Demographics}

Question 6. Does your current position carry any of the following responsibilities? (You can choose more than one)

$\square \quad$ Leading a department or a unit

$\square$ Leading working group(s) or project(s)

$\square$ Supervising staff

None of these

Question 7. Which is/are your major professional area(s) at your current position? (You can choose more than one)

Administration

$\square$ Access services (e.g. lending, interlibrary loan)

$\square$ Information services (e.g. reference, information literacy)

$\square$ Research services (e.g. data service, scholarly communication, digital scholarship)

$\square$ Collection services (e.g. acquisitions, cataloguing, collection development)

- Systems and facilities (e.g. ILS, computing equipment, space management)

- Special collections, archives

$\square \quad$ Others (please specify)

Question 8. How many years of experience do you have at your current position?

$\square \quad$ Less than 2 years

3-10 years

11-20 years

More than 20 years 
Question 9. How many years of experience do you have working in a library?

Less than 2 years

3-10 years

11-20 years

$\square \quad$ More than 20 years

Question 10. Which university library are you working in?

\section{Notes}

1. Shorlette Ammons-Stephens et al., "Developing Core Leadership Competencies for the Library Profession," Library Leadership \& Management 23, no. 2 (2009): 63-74.

2. Gabrielle K.W. Wong, "Leadership and Leadership Development in Academic Libraries: A Review," Library Management 38, no. 2/3 (2017): 153-66.

3. Matthew O'Connor, "A Review of Factors Affecting Individual Performance in Team Environments: Theories and Implications for Library Management," Library Management 27, no. 3 (2006): 135-43.

4. Pearl Ly, "Young and in Charge: Early Career Community College Library Leadership," Journal of Library Administration 55, no. 1 (2015): 60-68; Bonnie L. Fong, "Inspirational Innovation," Library Leadership \& Management 25, no. 4 (2011).

5. David A. Buchanan and Andrzej Huczynski, Organizational Behaviour: An Introductory Text, 5thed. (Harlow, England; New York: FT/Prentice Hall, 2004).

6. John P. Kotter, John P. Kotter on What Leaders Really Do, A Harvard Business Review Book (Boston: Harvard Business School Press, 1999), 52-53.

7. Richard Bolden, "What Is Leadership," Review, Leadership South West Research Report (University of Exeter Center for Leadership Studies, 2004).

8. David V. Day, “Leadership Development: A Review in Context,” Leadership Quarterly 11, no. 4 (2000): 581-613.

9. Arabella Advisors, "Cultivating Global Library Leadership: A Review of Leadership Training Programs for Librarians Worldwide," 2015; Irene M.H. Herold, "How to Develop Leadership Skills: Selecting the Right Program for You," Library Issues 35, no. 2 (2014); Peter Edward Sidorko, "Leadership Needs of Asian Librarians: An Account of an Asian Library Leadership Institute," in Continuing Professional Development: Pathways to Leadership in the Library and Information World, IFLA Publications 126 (Seventh World Conference on Continuing Professional Development and Workplace Learning, Johannesburg: K.G. Saur, 2007), 199-215; Katherine Skinner and Nick Krabbenhoeft, "Training the 21st Century Library Leader: A Review of Library Leadership Training, 1998-2013," Program Review, 2014.

10. Arabella Advisors, "Cultivating Global Library Leadership: A Review of Leadership Training Programs for Librarians Worldwide"; Florence M. Mason and Louella V. Wetherbee, "Learning to Lead: An Analysis of Current Training Programs for Library Leadership," Library Trends 53, no. 1 (2004): 187-217.

11. Jill Crawley-Low, "The Impact of Leadership Development on the Organizational Culture of a Canadian Academic Library," Evidence Based Library and Information Practice 8, no. 4 (2013): 60-77; Jill Mierke and Vicki Williamson, "A Framework for Achieving Organizational Culture Change," Library Leadership \& Management 31, no. 2 (2017): 1-16; Carissa Tomlinson, "Benefits of Internal Professional Development for Academic Librarians," in Revolutionizing the Development of Library and Information Professionals (Hershey, PA: Information Science Reference, an imprint of IGI Global, 2014), 76-89.

12. Morgan W. McCall Jr., "Leadership Development through Experience," Academy of Management Executive 18, no. 3 (2004): 127-30; D. Scott DeRue, "Developing Leaders via Experience: The Role of Developmental Challenge, Learning Orientation, and Feedback Availability," Journal of Applied Psychology 94, no. 4 (2009): 859-75.

13. Terrence Mech, "Leadership and the Evolution of Academic Librarianship," Journal of Academic Librarianship 22, no. 5 (1996): 352.

14. Colleen S. Harris-Keith, "What Academic Library Leadership Lacks: Leadership Skills Directors Are Least Likely to Develop, and Which Positions Offer Development Opportunity," Journal of Academic Librarianship 42, no. 4 (2016): 313-18.

15. Jill Mierke, “Leadership Development to Transform a Library," Library Management 35, no. 1/2 (2014): 69-77.

16. Margie Jantti, "Leadership Competencies: A Reference Point for Development and Evaluation," Library Management 33, no. 6/7 (2012): 421-28.

17. Angela Bridgland, "To Fill or How to Fill: That Is the Question: Succession Planning and Leadership Development in Academic Libraries," Australian Academic \& Research Libraries 30, no. 1 (1999): 20-29. 
18. Troy V. Mumford, Michael A. Campion, and Frederick P. Morgeson, "The Leadership Skills Strataplex: Leadership Skill Requirements across Organizational Levels," Leadership Quarterly 18, no. 2 (2007): 154-66.

19. James M. Kouzes and Barry Z. Posner, Learning Leadership: The Five Fundamentals of Becoming an Exemplary Leader (John Wiley \& Sons, 2016).

20. Peter Hernon, Ronald R. Powell, and Arthur P. Young, “University Library Directors in the Association of Research Libraries: The Next Generation, Part Two," College \& Research Libraries 63, no. 1 (2002): 73-90; Peter Hernon, Ronald R. Powell, and Arthur P. Young, "University Library Directors in the Association of Research Libraries: The Next Generation, Part One," College \& Research Libraries 62, no. 2 (2001): 116-46.

21. Examples of EI traits studies include: Peter Hernon and Nancy Rossiter, "Emotional Intelligence: Which Traits Are Most Prized?" College \& Research Libraries 67, no. 3 (2006): 260-75; Patricia A. Kreitz, "Leadership and Emotional Intelligence: A Study of University Library Directors and Their Senior Management Teams," College $\mathcal{E}$ Research Libraries 70, no. 6 (2009): 531-54.

22. John K. Lewis, The Academic Library in the 21st Century: Competencies Library Directors and Seniors Managers Must Possess to Successfully Lead Their Organizations into the Future (College Park: University of Maryland, 2015).

23. The top five leadership skills are vision, integrity, management skills, collaboration skills, and communication skills. See Binh P. Le, "Academic Library Leadership in the Digital Age," Library Management 36, no. 4/5 (2014): 300-314, https://doi.org/10.1108/LM-07-2014-0083.

24. See Jason Martin, "What Do Academic Librarians Value in a Leader? Reflections on Past Positive Library Leaders and a Consideration of Future Library Leaders," College \& Research Libraries 79, no. 6 (2018) 799-821.

25. Harris-Keith, "What Academic Library Leadership Lacks."

26. John Mullins and Margaret Linehan, "Desired Qualities of Public Library Leaders," Leadership E Organization Development Journal 27, no. 2 (2006): 133-43.

27. Robert G. Lord and Rosalie J. Hall, “Identity, Deep Structure and the Development of Leadership Skill,” Leadership Quarterly 16, no. 4 (2005): 592.

28. Nicholas Clarke, "An Integrated Conceptual Model of Respect in Leadership," Leadership Quarterly 22, no. 2 (2011): 316-27.

29. Mark A. Smylie and Jonathan Eckert, "Beyond Superheroes and Advocacy: The Pathway of Teacher Leadership Development," Educational Management Administration \& Leadership 46, no. 4 (2017): 1-22.

30. Michael D. Mumford et al., “Development of Leadership Skills: Experience and Timing," Leadership Quarterly 11, no. 1 (2000): 87-114.

31. Dave Bartram, Ivan T. Robertson, and Militza Callinan, "Introduction: A Framework for Examining Organizational Effectiveness," in Organizational Effectiveness: The Role of Psychology (John Wiley \& Sons, Inc., 2002), 1-10.

32. Joan Giesecke and Beth McNeil, "Core Competencies and the Learning Organization," Library Administration $\mathcal{E}$ Management 13, no. 3 (1999): 159.

33. Bartram, Robertson, and Callinan, "Introduction: A Framework for Examining Organizational Effectiveness," 7.

34. Richard Bolden and Jonathan Gosling, "Leadership Competencies: Time to Change the Tune?" Leadership 2, no. 2 (2006): 147-63.

35. Examples include ALA: www.ala.org/tools/atoz/library-competencies; CAVAL in Australia: https:// members.caval.edu.au/media/images/Documents/PDIG/CAVAL_PDIG_Competencies_2017.pdf; and Canadian Association of Research Libraries: www.carl-abrc.ca/strengthening-capacity/human-resource-management/ core-competencies-21st-century-carl-librarians/.

36. Ammons-Stephens et al., "Development Core Leadership Competencies for the Library Profession."

37. Ammons-Stephens et al., "Development Core Leadership Competencies for the Library Profession," 71.

38. Wong, "Leadership and Leadership Development in Academic Libraries: A Review."

39. Amy Chang and Kawanna Bright, "Changing Roles of Middle Manager in Academic Libraries," Library Management 33, no. 4/5 (2011): 213-20.

40. Fong, "Inspirational Innovation"; Ly, "Young and in Charge."

41. Bartram, Robertson, and Callinan, "Introduction: A Framework for Examining Organizational Effectiveness."

42. Bolden and Gosling, "Leadership Competencies: Time to Change the Tune?" 154.

43. Ammons-Stephens et al., "Development Core Leadership Competencies for the Library Profession."

44. The names of the eight universities can be found at the University Grants Committee webpage: www. ugc.edu.hk/eng/ugc/site/fund_inst.html [accessed 13 June 2018].

45. JULAC website: www.julac.org/ [accessed 13 June 2018].

46. Ammons-Stephens et al., "Development Core Leadership Competencies for the Library Profession," 69.

47. Crawley-Low, "The Impact of Leadership Development on the Organizational Culture of a Canadian Academic Library." 